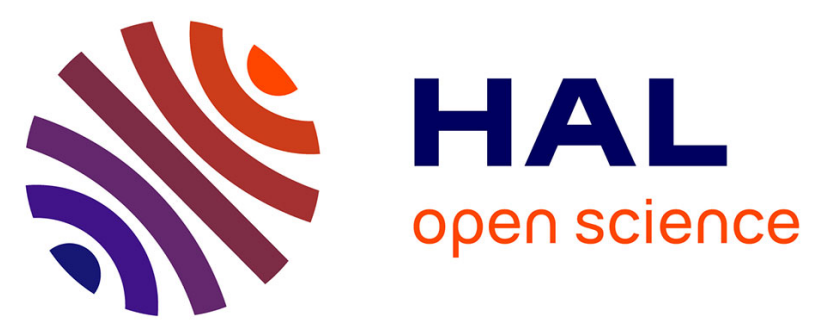

\title{
The growth responses of seedlings and plantlets to stress conditions in three anthocyaninless tomato (Lycopersicon esculentum Mill.) mutants
}

\author{
Bistra Atanassova, Lydia Shtereva, Elena Balacheva
}

\section{- To cite this version:}

Bistra Atanassova, Lydia Shtereva, Elena Balacheva. The growth responses of seedlings and plantlets to stress conditions in three anthocyaninless tomato (Lycopersicon esculentum Mill.) mutants. Agronomie, 2000, 20 (8), pp.907-916. 10.1051/agro:2000167 . hal-00886091

\section{HAL Id: hal-00886091 https://hal.science/hal-00886091}

Submitted on 1 Jan 2000

HAL is a multi-disciplinary open access archive for the deposit and dissemination of scientific research documents, whether they are published or not. The documents may come from teaching and research institutions in France or abroad, or from public or private research centers.
L'archive ouverte pluridisciplinaire HAL, est destinée au dépôt et à la diffusion de documents scientifiques de niveau recherche, publiés ou non, émanant des établissements d'enseignement et de recherche français ou étrangers, des laboratoires publics ou privés. 


\title{
The growth responses of seedlings and plantlets to stress conditions in three anthocyaninless tomato (Lycopersicon esculentum Mill.) mutants
}

\author{
Bistra Atanassova*, Lydia Shtereva, Elena Balacheva \\ Department of Heterosis, Institute of Genetics "Prof. D. Kostoff”, Bulgarian Academy of Sciences, Sofia 1113, Bulgaria
}

(Received 24 January 2000; accepted 2 August 2000)

\begin{abstract}
Genes ah, aw and bls speed up the germination in tomato. The present study was undertaken to test whether these genes might also influence the subsequent growth of seedlings and young plantlets under optimal and stress conditions. Two groups of experiments were carried out: (A) stress during the stages "germination-cotyledons emergence" and "cotyledons emergence-third expanded leaf" and (B) stress during the earlier stages "seed imbibition-radicle protrusion" and "radicle protrusion-cotyledons emergence". The results have shown that the earlier cotyledons emergence and more rapid plantlet development of the anthocyaninless mutants were due to their earlier germination. They depended on the genotype and on the treatment, and could not be attributed to their greater ability to recover after stress, or to more intensive growth under optimal and stress conditions.
\end{abstract}

Lycopersicon esculentum /anthocyaninless mutants / plantlets / seedlings / stress conditions

Résumé - Effet des conditions défavorables sur la croissance des radicules et des plantules chez trois mutants de tomate (Lycopersicon esculentum Mill.) caractérisés par l'absence d'anthocyane. Le but de l'étude était de tester l'hypothèse selon laquelle les trois gènes mutants $a h$, aw et bls qui accéléraient la germination chez la tomate dans des conditions optimales et défavorables pourraient exercer un effet similaire sur le développement ultérieur des radicules et des plantules. Deux groupes d'expériences ont été effectués : (a) application du stress durant les stades « germinationémergence des cotylédons » et «émergence des cotylédons-apparition de la troisième feuille » et (b) application du stress durant les stades précédents, i.e., « imbibition des graines-germination » et « germination-émergence des cotylédons ». Les résultats obtenus ont montré que l'accélération de l'émergence des cotylédons et du développement des plantules observée chez certains mutants sans anthocyane était liée à leur germination plus rapide et dépendait du génotype et du traitement. Cette accélération n'a pas pu être attribuée à une meilleure aptitude à recouvrer une croissance normale après un stress ou bien à un développement plus rapide en conditions optimales et défavorables.

Lycopersicon esculentum / absence d'anthocyane / stress / plantules / germination

Communicated by Christian Huyghe (Lusignan, France)

* Correspondence and reprints

an_zhelev@yahoo.com 


\section{Introduction}

In our previous studies, it was reported that three anthocyaninless genes ah (Hoffmann's anthocyaninless), aw (anthocyanin without) and bls (baby lea syndrome) enhanced tomato (Lycopersicon esculentum Mill.) germination under optimal conditions and a relatively large scale of stress conditions $[1,2]$. It was noticed, that under direct sowing and when producing transplants under non-heated or slightly heated greenhouse, cotyledons in the anthocyaninless lines generally emerged earlier than those of the anthocyanin-containing isogenic/near isogenic lines (IL/NILs). This trend was observed also all over the development of the young tomato plantlets. In many cases the anthocyaninless plantlets reached the 3-4 leaf stage earlier than the anthocyanin-containing counterparts.

Seedling emergence depends on both germination and the subsequent growth of root and hypocotyl [17]. A number of studies provided evidence that in Lycopersicon and other crop species tolerance to abiotic stress is a developmentally regulated, stage specific phenomenon. No uniform trend was found between plant responsiveness to stress at germination and that during seedling growth. In Lycopersicon the genetic relationships among tolerance at different developmental stages are unknown and usually no or only poor correlation was found between plant responsiveness to stress at germination and that during the subsequent seedling and plantlet's growth [4, 6, 17]. Thus, earlier emergence of cotyledons and earlier 3-4 leaf stage in the anthocyaninless plantlets might be due to their earlier germination and not to the more intensive seedling and plantlet growth.

However, it must be noted that the increased germination potential of the $a h-, a w$ - and $b l s$-genotypes was not due to tolerance to stress per se, but to some specific effect of the three anthocyaninless genes and in such a way that suggests this effect is more complex and not limited only to one seed characteristic [1]. Mutations $a h$ and bls were characterized as resulting in coordinate reduction in all three activities: DFR (dihydroflavonol 4-reductase),
CHS (chalcone synthase) and FHT (flavone 3 hydroxylase). Mutation aw specifically and completely eliminated DFR activity [19]. Recently, diverse functions and benefits concerning stress tolerance were attributed to a variety of compounds produced by the branched flavonoid biosynthesis pathway. For example, it was found that flavonoids probably protected plants from harmful UV-B radiation [7,10].

Thus, it might be suggested that in addition to increasing the germination potential, genes $a h, a w$ and $b l s$ might also influence the subsequent growth of root, hypocotyl and young plantlet. Bearing in mind that in Lycopersicon, like in many other crops, seedling and young plantlet are vulnerable to stress, as well as the fact that the initial plant stand affects the final production, it was tempting to test this hypothesis. On the other hand, since genes $a h, a w$ and $b l s$ were found to enhance germination regardless of the nature and the intensity of the stress [1,2], $a h$-, $a w$ - and $b l s$-anthocyaninless lines could probably be used in developing tomato cultivars and hybrids tolerant to stress at germination. In this sense improving the genetic and physiological characterization of the three anthocyaninless genes and the knowledge of their effect during the subsequent developmental stages, might be useful for tomato breeding.

The present study was therefore designed to evaluate hypocotyl, root and young plantlet growth responses of tomato isogenic/near isogenic lines differing for genes $a h$, aw and bls under optimal and four types of stress conditions: low and high temperature, salinity and osmotic treatments.

\section{Materials and methods}

\subsection{Plant material}

The study was performed on two tomato lines Ailsa Craig and Apedice - that strongly differed in their tolerance to stress at germination [2] and in their $a h-, a w$ - and $b l s$-IL/NILs described by Maxon-Smith and Ritchie [11], Philouze [15], Rick and Chetelat [16]. Seeds were kindly provided by 
Philouze (Station d'Amélioration des Plantes Maraîchères, Monfavet-Avignon) and Prof. Rick (TGRC, University of California, Davis). The line Ailsa Craig aw $\left(\mathrm{BC}_{5}\right)$ was created by backcrossing line LA 277 aw with Ailsa Craig. Each experiment was repeated at least three times and was carried out using seeds produced in the same year and under the same climatic conditions.

\subsection{Growth conditions}

The following developmental stages were studied: seed imbibition-radicle protrusion; radicle protrusion-cotyledon's emergence; cotyledon's emergence-third leaf. All experiments were conducted in the dark up to cotyledon's emergence and further on under $16 \mathrm{~h}$ daylength.

Optimal conditions: The experiments were carried out at $25{ }^{\circ} \mathrm{C}$ up to cotyledon's emergence and further on under day/night temperature $26^{\circ} / 19^{\circ} \mathrm{C}$.
Stress conditions: Seeds were germinated under treatment parameters established on the basis of those described in the literature [2, 5, 17, 18]: (a) low temperature $14 \pm 1{ }^{\circ} \mathrm{C}$; (b) high temperature $33 \pm 1{ }^{\circ} \mathrm{C}$; (c) salt stress $100 \mathrm{mM} \mathrm{NaCl}$ water solution; (d) osmotic stress 15\% PEG-6000 water solution. Root, hypocotyl and plantlet growth responses were evaluated under the same stress treatments. They were similar to those under which we have observed direct sowing and slightly heated greenhouse growth, and under which differences in seedling and plantlet growth within some series of IL/NILs were observed.

\subsection{Design of the experiments}

In order to get further information on the relationship between the speed of germination under optimal or suboptimal conditions and the subsequent seedling and plantlet development, four experiments were carried out (Tab. I).

Table I. Design of the experiments.

\begin{tabular}{|c|c|c|c|}
\hline \multirow{2}{*}{$\begin{array}{l}\text { Experiment } \\
\text { A. Seedling growth }\end{array}$} & \multicolumn{2}{|c|}{ Developmental stage and growth conditions } & \multirow{2}{*}{ 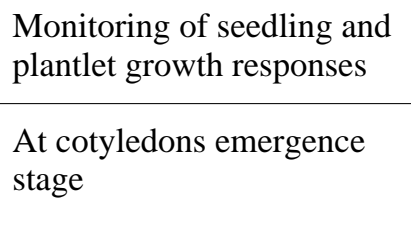 } \\
\hline & $\begin{array}{l}\text { (1) seed imbibition- } \\
\text { radicle protrusion } \\
\text { (optimal conditions) }\end{array}$ & $\begin{array}{l}\text { radicle protrusion- } \\
\text { cotyledons emergence } \\
\text { (under stress) }\end{array}$ & \\
\hline & $\begin{array}{l}\text { (2) seed imbibition- } \\
\text { radicle protrusion } \\
\text { (under stress) }\end{array}$ & $\begin{array}{l}\text { radicle protrusion- } \\
\text { cotyledons emergence } \\
\text { (optimal conditions) }\end{array}$ & $\begin{array}{l}\text { (a) } 9 \text { days after seed } \\
\text { imbibition under PEG; } \\
12 \text { days after seed imbibition } \\
\text { under } 33{ }^{\circ} \mathrm{C} \text { and } \mathrm{NaCl} \text {; } \\
17 \text { days after seed imbibition } \\
\text { under } 14^{\circ} \mathrm{C} \text { treatment } \\
\text { (b) At the end of } 7 \text { days of } \\
\text { development under optimal } \\
\text { conditions }\end{array}$ \\
\hline \multirow[t]{2}{*}{ B. Plantlet growth } & $\begin{array}{l}\text { (1) seed imbibition- } \\
\text { cotyledons emergence } \\
\text { (optimal conditions) }\end{array}$ & $\begin{array}{l}\text { cotyledons emergence- } \\
\text { third leaf (under stress) }\end{array}$ & $\begin{array}{l}\text { At the end of } 35 \text { days } \\
\text { treatment period }\end{array}$ \\
\hline & $\begin{array}{l}\text { (2) seed imbibition- } \\
\text { cotyledons emergence } \\
\text { (under stress) }\end{array}$ & $\begin{array}{l}\text { cotyledons emergence- } \\
\text { third leaf (optimal } \\
\text { conditions) }\end{array}$ & $\begin{array}{l}\text { (a) } 50 \text { days after sowing, } \\
\text { (b) } 15 \text { days after plantlet } \\
\text { exposure to optimal } \\
\text { conditions }\end{array}$ \\
\hline
\end{tabular}


Table II. Mean number of days to cotyledons emergence in tomato IL/NILs differing for genes $a h$, $a w$ and $b l s$ under optimal and stress conditions.

\begin{tabular}{lccccc}
\hline Genotypes & $24{ }^{\circ} \mathrm{C}$ (days) & $14{ }^{\circ} \mathrm{C}$ (days) & $33{ }^{\circ} \mathrm{C}$ (days) & $100 \mathrm{mM} \mathrm{NaCl}$ (days) & $15 \%$ PEG - 6000 (days) \\
\hline Ailsa Craig & $5.2 \pm 0.3 \mathrm{a}$ & $26.0 \pm 1.3 \mathrm{a}$ & $12.2 \pm 1.0 \mathrm{a}$ & $17.6 \pm 0.9 \mathrm{a}$ & $9.0 \pm 0.3 \mathrm{a}$ \\
Ailsa Craig $a h$ & $3.6 \pm 0.5 \mathrm{~b}$ & $21.0 \pm 1.0 \mathrm{~b}$ & $9.5 \pm 1.1 \mathrm{~b}$ & $15.2 \pm 0.4 \mathrm{~b}$ & $6.9 \pm 0.2 \mathrm{~b}$ \\
Ailsa Craig $a w$ & $4.3 \pm 0.3 \mathrm{~b}$ & $21.5 \pm 2.0 \mathrm{~b}$ & $11.0 \pm 1.3 \mathrm{ab}$ & $15.8 \pm 0.4 \mathrm{~b}$ & $9.0 \pm 0.5 \mathrm{a}$ \\
Ailsa Craig $\mathrm{bls}$ & $3.7 \pm 0.4 \mathrm{~b}$ & $20.2 \pm 0.7 \mathrm{~b}$ & $10.3 \pm 0.9 \mathrm{ab}$ & $14.2 \pm 0.3 \mathrm{~b}$ & $8.1 \pm 0.4 \mathrm{ab}$ \\
Apedice & $4.2 \pm 0.3 \mathrm{a}$ & $21.0 \pm 0.5 \mathrm{a}$ & $12.0 \pm 0.7 \mathrm{a}$ & $14.1 \pm 0.2 \mathrm{a}$ & $7.5 \pm 0.5 \mathrm{a}$ \\
Apedice $a w$ & $3.6 \pm 0.4 \mathrm{a}$ & $20.0 \pm 0.9 \mathrm{a}$ & $10.0 \pm 0.5 \mathrm{~b}$ & $13.4 \pm 0.6 \mathrm{ab}$ & $8.0 \pm 0.6 \mathrm{a}$ \\
Apedice $b l s$ & $3.5 \pm 0.2 \mathrm{a}$ & $19.0 \pm 1.4 \mathrm{ab}$ & $9.5 \pm 0.4 \mathrm{~b}$ & $13.8 \pm 0.3 \mathrm{a}$ & $6.5 \pm 0.1 \mathrm{a}$ \\
\hline
\end{tabular}

Significant at $P<0.05$.

In the experiments A 2 and B 2, under the four treatments tested both seeds and cotyledons of some of the anthocyaninless lines germinated and emerged earlier than the anthocyanin-containing IL/NILs, and this depended on the genotype and the treatment [2] (Tab. II). This required them to be transferred earlier than the anthocyanin-containing ones to optimal conditions. For this reason seedling or plantlet growth responses were monitored (a) based on the number of days from sowing and (b) based on some fixed number of days that they have spent under optimal conditions after the end of the stress pretreatment.

\subsection{Seedling growth and measurements}

A total of 20 germinated seeds (10 seeds per variant) selected at the same stage of germination based on $0.5 \mathrm{~mm}$ radicle protrusion were planted in transparent growth columns assembled using $800 \mathrm{ml}$ glass beakers as described by Muthiah et al. [13]. The experiment was conducted in four replicates of 10 seeds. Seedling development was monitored by measuring hypocotyl and root lengths for each seedling as detailed in Orbovic and Kieu [14] at an interval of 24 or 48 hours depending on the treatment.

In experiment A 2 seeds of the anthocyanin-containing IL/NILs were transferred later to optimal conditions as follows: (a) under low temperature: Ailsa Craig 5.2 \pm 0.5 days, Apedice $1.2 \pm 0.2$; (b) under high temperature: Ailsa Craig $1.0 \pm 0.2$,
Apedice $1.7 \pm 0.4$; (c) under $120 \mathrm{mM} \mathrm{NaCl}$ : Ailsa Craig $2.7 \pm 0.4$, Apedice $1.5 \pm 0.2$; under $15 \%$ PEG 6000: Ailsa Craig $2.0 \pm 0.1$, Apedice $0.5 \pm$ $0.1,[2]$.

\subsection{Plantlet growth and measurement}

In experiment B1 seeds of the tomato IL/NILs were sown on perlite, in plastic trays that were fertilized weekly with Hoagland and Arnon solution [8]. Upon the cotyledon's emergence seedlings designated to be tested under drought and salinity stress were transferred to plastic pots and were grown as water culture on nutrient solution, [8] in which the osmotically active substance (PEG 6000 or $\mathrm{NaCl}$ ) were added. Control plantlets were grown under optimal conditions. At the end of the 35 days treatment period the plantlets were harvested and the fresh leaf, stem and root material was weighed. The experiments were conducted in four replicates of 20 plantlets.

In experiment $\mathrm{B} 2$ seeds of the tomato anthocyanin-containing IL/NILs were sown separately from the anthocyaninless ones as the latter had to be transferred earlier to optimal conditions because of the earlier cotyledon's emergence (Tab. II). In the experiments with PEG 6000 and $\mathrm{NaCl}$ stress, seeds from each variant were planted in separate transparent growth columns and were grown up to cotyledon's emergence in the same way as described above. At cotyledon's emergence seedlings were transplanted on perlite in plastic 
trays. Plantlets were harvested and the fresh leaf, stem and root material was weighed as indicated in Table I: (a) 50 days after sowing and (b) 15 days after exposure of the seedlings to optimal conditions.

\subsection{Statistical analysis}

The results were expressed as the means and standard errors calculated from replicates [9]. The number of days to $50 \%$ cotyledon's emergence, root, leaves and stems weights data were analyzed by Duncan multiple range test [3]. The Duncan test was applied separately for each group of IL/NILs and for each treatment.

\section{Results}

\subsection{Seedling growth responses}

As shown in Table III no significant differences in root and hypocotyl lengths between the anthocyaninless and the anthocyanin-containing IL/NILs were detected under optimal conditions.

When the stress was initiated at the stage of radicle protrusion in the seeds (Tab. IV A), the same lack of significant differences in these two parameters were observed between the wild-type lines and their $a h-, a w$ - and $b l s$ - IL/NILs. On the contrary, when the stress was applied at the stage of seed imbibition, radicle protrusion and the measurements were done based on the number of days from sowing, the hypocotyl and the root in some anthocyaninless IL/NILs were longer than those of the wild-type (Tab. IV B). The differences varied depending on the genotype and on the treatment. For example, the differences in the characteristics observed within the Ailsa Craig series were particularly significant under low temperature and not significant under $33{ }^{\circ} \mathrm{C}$ pretreatment. In the anthocyaninless IL/NILs from Apedice, under $33{ }^{\circ} \mathrm{C}$ and $\mathrm{NaCl}$ pretreatment, the root and the hypocotyl were longer than those in Apedice. However, it must be noted that some of the differences observed were on the verge of being significant. Under low temperature and PEG 6000 pretreatment no significant differences concerning these parameters were detected. Monitoring of the parameters studied 7 days after the end of the stress treatment showed that no significant differences in root and hypocotyl length between the anthocyaninless and the anthocyanin-containing IL/NILs were detected (Tab. IV C).

\subsection{Plantlet growth responses}

The means and standard deviations for the anthocyanin containing lines and their anthocyaninless IL/NILs in terms of characteristics observed are presented in Table II and Table V.

Table III. Mean length of root and hypocotyl/per seedling and mean plantlets weight at the stage third leaf in tomato IL/NILs grown under optimal conditions.

\begin{tabular}{|c|c|c|c|c|}
\hline \multirow[t]{2}{*}{ Genotypes } & \multicolumn{2}{|c|}{ Seedling length $(\mathrm{cm})$} & \multicolumn{2}{|c|}{ Plantlets weight (mg) } \\
\hline & root & hypocotyl & leaves and stem & root \\
\hline Ailsa Craig & $4.6 \pm 0.4 a$ & $3.9 \pm 0.3 \mathrm{a}$ & $234 \pm 8 a$ & $39 \pm 3 a$ \\
\hline Ailsa Craig $a h$ & $5.2 \pm 0.3 \mathrm{a}$ & $4.0 \pm 0.3 \mathrm{a}$ & $229 \pm 5 a$ & $40 \pm 6 a$ \\
\hline Ailsa Craig $a w$ & $5.4 \pm 0.2 \mathrm{ab}$ & $4.2 \pm 0.5 \mathrm{a}$ & $223 \pm 10 \mathrm{a}$ & $42 \pm 2 \mathrm{a}$ \\
\hline Ailsa Craig bls & $5.2 \pm 0.6 a$ & $3.9 \pm 0.2 \mathrm{a}$ & $236 \pm 7 a$ & $44 \pm 5 a$ \\
\hline Apedice & $5.5 \pm 0.2 \mathrm{a}$ & $4.3 \pm 0.1 \mathrm{a}$ & $217 \pm 9 a$ & $38 \pm 7 a$ \\
\hline Apedice $a w$ & $5.8 \pm 0.4 a$ & $4.7 \pm 0.2 \mathrm{a}$ & $240 \pm 5 b$ & $42 \pm 7 a$ \\
\hline Apedice $b l s$ & $5.3 \pm 0.3 \mathrm{a}$ & $4.4 \pm 0.4 \mathrm{a}$ & $215 \pm 2 \mathrm{a}$ & $37 \pm 8 \mathrm{a}$ \\
\hline
\end{tabular}

Significant at $P<0.05$. 
Table IV. Root and hypocotyl growth responses (mean length per seedling in $\mathrm{cm}$ ) of tomato IL/NIL's (A) to stress applied at the stage radicle protrusion-cotyledon emergence; (B) to stress applied at the stage seed imbibition-radicle protrusion and subsequent transfer to optimal conditions; monitoring done on the basis of number of days after seed imbibition (9 days under PEG, 12 days under $33{ }^{\circ} \mathrm{C}$ and $\mathrm{NaCl}$ and 17 days under $14{ }^{\circ} \mathrm{C}$ ); (C) to stress applied at the stage seed imbibition-radicle protrusion and 7 days of subsequent development under optimal conditions.

The Duncan test was applied separately for each group of IL/NILs and for each treatment.

\begin{tabular}{|c|c|c|c|c|c|c|c|c|}
\hline \multirow[t]{2}{*}{ Genotypes } & \multicolumn{2}{|c|}{$14^{\circ} \mathrm{C}$} & \multicolumn{2}{|l|}{3} & \multicolumn{2}{|c|}{$100 \mathrm{mM} \mathrm{NaCl}$} & \multicolumn{2}{|c|}{$15 \%$ PEG-6000 } \\
\hline & root & hypocotyl & root & hypocotyl & root & hypocotyl & root & hypocotyl \\
\hline \\
\hline Craig & $0 \pm 0.2 \mathrm{a}$ & $2.0 \pm 0.3 \mathrm{a}$ & $3.6 \pm 0.5 \mathrm{a}$ & $3.0 \pm 0.2 \mathrm{a}$ & $4.1 \pm 0.5 \mathrm{a}$ & $3.3 \pm 0.3 \mathrm{a}$ & $5.1 \pm 0.3 a$ & $2.8 \pm 0.3 \mathrm{a}$ \\
\hline A. Craig $a h$ & $\pm 0.4 a$ & & & & & & & \\
\hline A. Craig $a w$ & & & & & & & $6.0 \pm 0.4 a b$ & \\
\hline . Craig bls & $4 \pm 0.3 a$ & 2.2 & $8 \pm 0.2 a$ & & $5 \pm 0.3 a$ & & $5.4 \pm 0.2 \mathrm{a}$ & \\
\hline Apedice & $4 \pm 0.1 \mathrm{a}$ & 2.3 & $3.7 \pm 0.1 \mathrm{a}$ & $3 \mathrm{a}$ & $.0 \pm 0.3 \mathrm{a}$ & $3.6=$ & $6.8 \pm 0.5 \mathrm{a}$ & $3.3 \pm 0.2 \mathrm{a}$ \\
\hline & & & & & & & & \\
\hline Apedice $b l s$ & $\pm 0.3 a$ & & & & & & & \\
\hline \\
\hline A. $\mathrm{C}$ & $7 \pm 0.1 \mathrm{a}$ & $0.2 \pm$ & $3 \pm 0.4 a$ & $5.7 \pm 0.3 \mathrm{a}$ & $3.0 \pm 0.3 \mathrm{a}$ & $2.0 \pm 0.2 \mathrm{a}$ & $3.2 \pm 0.2 \mathrm{a}$ & $2.5 \pm 0.1 \mathrm{a}$ \\
\hline $\mathrm{g} a \mathrm{~h}$ & & & & & & & & \\
\hline 1. Craig $a w$ & $0 \pm 0.6 b c$ & $6.9=$ & $7.3 \pm 0.7 \mathrm{a}$ & $6.0=$ & $4.2 \pm 0.2 b$ & 4.1 & $4.0 \pm 0.5 \mathrm{ab}$ & $3.2 \pm 0.3 \mathrm{ab}$ \\
\hline A. Craig $b l s$ & $7.4 \pm 0.2 b$ & & & & $4.8 \pm 0.2 b$ & & $5.4 \pm 0.3 b$ & $4.2 \pm 0.5 b$ \\
\hline & $\pm 0.2 \mathrm{a}$ & 5.3 & & & $=0.3 \mathrm{a}$ & 4.1 & $6.3 \pm 0.1 \mathrm{a}$ & $0.1 \mathrm{a}$ \\
\hline & $2 \pm 0.4 a$ & $5.6=$ & & & $7.9 \pm 0.5 b$ & $5.7 \pm$ & $6.0 \pm 0.4 a$ & $4.3 \pm 0$. \\
\hline Apedice $b l s$ & $7.0 \pm 0.3 \mathrm{a}$ & $5.1 \pm 0.4 a$ & $7.0 \pm 0.2 b$ & $5.7 \pm 0.4 a b$ & $7.0 \pm 0.4 \mathrm{ab}$ & $4.6 \pm 0.2 \mathrm{a}$ & $7.1 \pm 0.6 a b$ & $4.7 \pm 0.2 \mathrm{ab}$ \\
\hline \\
\hline$C_{n}$ & & & & & & & & \\
\hline aig $a h$ & & & & & & & $6.0 \pm 0$ & $4.7 \pm 0$ \\
\hline & & & & & & & & \\
\hline & $3 \pm 0.4 a$ & & & & $5.3 \pm 0.2 \mathrm{a}$ & & & $4.5 \pm 0.1 \mathrm{a}$ \\
\hline Apedice & $7.0 \pm 0.1 \mathrm{a}$ & $5.5 \pm 0.2 \mathrm{a}$ & $6.8 \pm 0.4 a$ & $6.0 \pm 0.1 \mathrm{a}$ & $6.9 \pm 0.1 \mathrm{a}$ & $5.2 \pm 0.5 \mathrm{a}$ & $6.1 \pm 0.4 a$ & $5.2 \pm 0.3 a$ \\
\hline & & & & & & & & \\
\hline Apedice $b l s$ & $7.2 \pm 0.3 \mathrm{a}$ & $5.5 \pm 0.2 \mathrm{a}$ & $7.4 \pm 0.2 \mathrm{a}$ & $6.1 \pm 0.2 \mathrm{a}$ & $6.9 \pm 0.3 a$ & $5.0 \pm 0.3 a$ & $6.0 \pm 0.1 \mathrm{a}$ & $5.0 \pm 0.3 \mathrm{a}$ \\
\hline
\end{tabular}

Significant at $P<0.05$.

From these results it can be seen that under optimal conditions no differences in root and shoot fresh weights between the anthocyanin-containing and their anthocyaninless IL/NILs were detected except between Apedice and Apedice aw (Tab. III). This same trend was observed when the stress was initiated at cotyledon's emergence (Tab. V A).

Stress application at the stage "seed imbibitioncotyledon's emergence" resulted in plantlet growth responses that at first view might seem contradictory (Tabs. V B and V C). When the plantlet growth responses were monitored with the number of days from sowing for both anthocyaninless and anthocyanin-containing plantlets, significant differences in fresh weights were detected between some anthocyaninless and anthocyanin-containing IL/NILs (Tab. V B). The differences varied depending on the treatment and on the genotype. Monitoring of plantlet performance 15 days after the end of the stress pretreatment provided evidence that the anthocyaninless and the anthocyanin-containing plantlets within one series of IL/NILs did not differ in their ability to recover after the end of the stresses (Tab. V C). However, 
Table V. Plantlet's growth responses (mean fresh weight $\cdot$ plant ${ }^{-1} \cdot \mathrm{mg}^{-1}$ ) of tomato IL/NILs: (A) to stress applied at the stage cotyledons emergence-third leaf; (B) 50 days after sowing, stress applied at the stage seed imbibition-cotyledon emergence and subsequent development under optimal conditions; (C) stress applied at the stage seed imbibitioncotyledon emergence and 15 days of subsequent development under optimal conditions.

The Duncan test was applied separately for each group of IL/NILs and for each treatment.

\begin{tabular}{|c|c|c|c|c|c|c|}
\hline \multirow[t]{2}{*}{ Genotypes } & \multicolumn{2}{|c|}{$14^{\circ} \mathrm{C}$} & \multicolumn{2}{|c|}{$33^{\circ} \mathrm{C}$} & 100 mM NaCl & $15 \%$ PEG-6000 \\
\hline & $\begin{array}{l}\text { leaves } \\
\text { and stem }\end{array}$ & root & $\begin{array}{l}\text { leaves } \\
\text { and stem }\end{array}$ & root & $\begin{array}{cc}\text { leaves } & \text { root } \\
\text { and stem } & \end{array}$ & $\begin{array}{cc}\text { leaves } & \text { root } \\
\text { and stem } & \end{array}$ \\
\hline
\end{tabular}

A.

\begin{tabular}{|c|c|c|c|c|c|c|c|c|}
\hline A. Craig & $145 \pm 12 \mathrm{a}$ & $20 \pm 1 a$ & $174 \pm 10 a$ & $18 \pm 7 a$ & $164 \pm 8 a$ & $38 \pm 7 a$ & $189 \pm 12 \mathrm{a}$ & $42 \pm 3 a$ \\
\hline A. Craig $a h$ & $149 \pm 15 a$ & $23 \pm 4 a$ & $177 \pm 12 \mathrm{a}$ & $21 \pm 2 \mathrm{a}$ & $167 \pm 17 a$ & $38 \pm 3 a$ & $178 \pm 4 a$ & $43 \pm 6 a$ \\
\hline A. Craig aw & $143 \pm 3 a$ & $22 \pm 4 a$ & $172 \pm 14 a$ & $19 \pm 5 a$ & $170 \pm 12 \mathrm{a}$ & $40 \pm 2 a$ & $180 \pm 10 a$ & $47 \pm 4 a$ \\
\hline A. Craig bls & $140 \pm 16 a$ & $19 \pm 2 a$ & $169 \pm 8 a$ & $16 \pm 3 a$ & $169 \pm 5 a$ & $35 \pm 5 a$ & $198 \pm 17 a$ & $39 \pm 5 a$ \\
\hline Apedice & $128 \pm 9 a$ & $24 \pm 5 a$ & $183 \pm 9 a$ & $28 \pm 6 a$ & $137 \pm 15 a$ & $33 \pm 8 a$ & $216 \pm 9 a$ & $44 \pm 2 a$ \\
\hline Apedice $a w$ & $133 \pm 5 a$ & $21 \pm 3 a$ & $180 \pm 11 \mathrm{a}$ & $28 \pm 1 \mathrm{a}$ & $136 \pm 8 a$ & $38 \pm 4 a$ & $205 \pm 5 a$ & $41 \pm 3 a$ \\
\hline Apedice $b l s$ & $141 \pm 8 \mathrm{ab}$ & $28 \pm 6 a$ & $193 \pm 15 a$ & $28 \pm 3 a$ & $142 \pm 13 a$ & $32 \pm 7 a$ & $249 \pm 14 b$ & $46 \pm 8 a$ \\
\hline
\end{tabular}

B.

\begin{tabular}{|c|c|c|c|c|c|c|c|c|}
\hline A. Craig & $363 \pm 17 a$ & $28 \pm 4 a$ & $429 \pm 9 a$ & $36 \pm 3 a$ & $377 \pm 13 a$ & $38 \pm 2 \mathrm{a}$ & $418 \pm 18 a$ & $40 \pm 3 a$ \\
\hline A. Craig $a h$ & $419 \pm 12 b$ & $34 \pm 2 \mathrm{ab}$ & $418 \pm 11 a$ & $38 \pm 2 \mathrm{a}$ & $395 \pm 8 b$ & $40 \pm 3 a$ & $422 \pm 14 a$ & $43 \pm 6 a$ \\
\hline A. Craig $a w$ & $400 \pm 7 b$ & $33 \pm 1 \mathrm{ab}$ & $433 \pm 13 a$ & $39 \pm 4 a$ & $402 \pm 10 b$ & $43 \pm 2 \mathrm{ab}$ & $431 \pm 15 a$ & $39 \pm 2 a$ \\
\hline A. Craig bls & $404 \pm 14 b$ & $34 \pm 2 \mathrm{ab}$ & $441 \pm 16 a$ & $33 \pm 3 a$ & $388 \pm 7 a$ & $39 \pm 2 a$ & $410 \pm 8 \mathrm{a}$ & $38 \pm 3 a$ \\
\hline Apedice & $392 \pm 6 a$ & $29 \pm 5 a$ & $400 \pm 8 a$ & $27 \pm 5 a$ & $385 \pm 14 a$ & $42 \pm 4 a$ & $414 \pm 19 a$ & $42 \pm 4 a$ \\
\hline Apedice $a w$ & $411 \pm 11 \mathrm{ab}$ & $29 \pm 1 a$ & $425 \pm 14 b$ & $32 \pm 1 a$ & $404 \pm 12 \mathrm{ab}$ & $45 \pm 6 a$ & $419 \pm 5 a$ & $40 \pm 5 a$ \\
\hline Apedice $b l s$ & $397 \pm 9 a$ & $28 \pm 2 a$ & $419 \pm 6 b$ & $29 \pm 3 a$ & $388 \pm 16 a$ & $40 \pm 1 a$ & $407 \pm 16 a$ & $41 \pm 1 \mathrm{a}$ \\
\hline \multicolumn{9}{|l|}{$\mathrm{C}$} \\
\hline A. Craig & $210 \pm 6 a$ & $19 \pm 1 \mathrm{a}$ & $224 \pm 8 a$ & $20 \pm 4 a$ & $197 \pm 7 a$ & $25 \pm 4 a$ & $236 \pm 14 a$ & $24 \pm 2 \mathrm{a}$ \\
\hline A. Craig $a h$ & $229 \pm 9 b$ & $24 \pm 2 b$ & $219 \pm 11 \mathrm{a}$ & $22 \pm 4 a$ & $211 \pm 13 a$ & $23 \pm 3 a$ & $227 \pm 8 \mathrm{a}$ & $24 \pm 3 a$ \\
\hline A. Craig $a w$ & $219 \pm 10 \mathrm{a}$ & $20 \pm 1 a$ & $231 \pm 13 a$ & $19 \pm 2 \mathrm{a}$ & $203 \pm 9 a$ & $26 \pm 3 a$ & $239 \pm 10 a$ & $23 \pm 2 \mathrm{a}$ \\
\hline A. Craig bls & $207 \pm 5 a$ & $19 \pm 2 \mathrm{a}$ & $213 \pm 12 \mathrm{a}$ & $21 \pm 1 \mathrm{a}$ & $208 \pm 5 a$ & $21 \pm 2 \mathrm{a}$ & $233 \pm 9 a$ & $25 \pm 2 \mathrm{a}$ \\
\hline Apedice & $228 \pm 14 a$ & $22 \pm 3 a$ & $207 \pm 6 a$ & $21 \pm 2 \mathrm{a}$ & $219 \pm 8 a$ & $24 \pm 3 a$ & $222 \pm 10 \mathrm{a}$ & $22 \pm 3 a$ \\
\hline Apedice $a w$ & $249 \pm 4 a b$ & $22 \pm 1 a$ & $205 \pm 11 \mathrm{a}$ & $24 \pm 3 a$ & $222 \pm 14 a$ & $28 \pm 4 a$ & $230 \pm 5 a$ & $25 \pm 4 a$ \\
\hline Apedice $b l s$ & $233 \pm 8 a$ & $19 \pm 2 a$ & $197 \pm 15 a$ & $22 \pm 2 a$ & $213 \pm 10 a$ & $23 \pm 1 a$ & $234 \pm 13 a$ & $20 \pm 2 a$ \\
\hline
\end{tabular}

Significant at $P<0.05$.

there was an exception to be mentioned: mean fresh weight in Ailsa Craig ah was higher than that of Ailsa Craig under low temperature.

\section{Discussion}

The present study aimed at analyzing the growth responses of seedlings and plantlets under optimal and stress conditions in tomato anthocyanin-con- taining and $a h$-, $a w$ - and $b l s$-IL/NILs. No significant differences in seedling growth responses between the anthocyanin-containing and the anthocyaninless genotypes were detected when the stress was applied at the stage of radicle protrusioncotyledon's emergence. It suggested that the enhancing effect of genes $a h, a w$ and $b l s$ on germination was probably limited to the stage of radicle protrusion. On the other hand, when the stress was applied at the stage of seed imbibition-radicle protrusion and the comparison was made based on an 
equal number of days from seed imbibition, no uniformity in the anthocyanin-containing and anthocyaninless seedling growth responses was observed (Tab. IV B). These results were consistent with the data concerning seedling rate of development under optimal and stress conditions (Tab. II).

It was established in our previous studies that Ailsa Craig was characterised as a slowly germinating line, highly sensitive to low temperature, salinity and drought and moderately tolerant to high temperature treatment at germination. Apedice performed as a rapidly germinating line, tolerant to low temperature, moderately tolerant to salinity and PEG 6000 and sensitive to high temperature stress [2]. Thus, under drought, salinity and particularly under low temperature treatments the anthocyaninless IL/NILs from Ailsa Craig germinated significantly earlier than the wild-type line. In Apedice the anthocyaninless IL/NILs germinated earlier than the wild-type line under high temperature and $\mathrm{NaCl}$ treatment. Therefore all of them had to be transferred earlier to optimal conditions. In this way, when monitoring seedling growth responses based on an equal number of days from sowing, the anthocyaninless genotypes have developed for a longer period under favourable optimal conditions. For this reason they could normally possess longer root and hypocotyl than the anthocyanin-containing ones.

So, the differences observed were not probably due to the more intensive growth of the anthocyaninless seedlings under stress, but to their more rapid germination. The latter conditioned the earlier cotyledons emergence and earlier transfer to optimal conditions. The suggestion that genes $a h$, $a w$ and $b l s$ had no effect on seedling growth under stress conditions was confirmed by two additional facts. Firstly, as shown in Table IV B, when the treatment was applied at the stage of seed imbibition-radicle protrusion, no differences in root and hypocotyl elongation were found in the Ailsa Craig series under high temperature and in the Apedice series under low temperature. Thus, the differences or their lack in hypocotyl and root length between the anthocyanin containing and the anthocyaninless seedlings correlated with the performance of genotypes under stress at germination. Secondly, when seedling growth responses were recorded based on an equal number of days after the end of the stress treatment for both anthocyanin-containing and anthocyaninless seedlings, no differences in the parameters investigated were detected. Therefore, stress treatment applied during the period preceding radicle protrusion did not result in differences in growth responses between the anthocyanin-containing and the anthocyaninless seedlings per se. It rather resulted in earlier germination of the last ones and their earlier cotyledons emergence. This suggestion is consistent with the finding that fast germination ensures rapid seedling establishment [18].

The results concerning plantlet performance under optimal and stress conditions were consistent with the results obtained from the experiments with seedlings. As shown in Table III and Table V, plantlet development under optimal conditions and stress initiation at the stage of cotyledon's emergence resulted in identical performance of the anthocyanin-containing and the anthocyaninless IL/NILs for the two characteristics observed. When the stress was applied at the stage of seed imbibition-cotyledon's emergence and the monitoring based on the number of days from sowing, in some cases the anthocyaninless lines significantly exceeded the anthocyanin-containing ones in mean fresh weight per plant (Tab. V B). Such a performance was not surprising. Cotyledons in the anthocyaninless lines emerged earlier, which conditioned their earlier transfer to optimal conditions and consequently a longer recovery period after the end of the stress. The exceptions observed might be attributed to the fact that the lines studied are near isogenic and might differ for other genes, different from $a h, a w$ and bls. On the other hand, there is a probability that the reactions of the anthocyaninless lines might result from the interaction between genotype; anthocyaninless mutation and the nature of the stress is also not to be neglected.

Based on these findings it might be assumed that the higher fresh weight in the anthocyaninless plantlets under the four treatments studied was not due to their more intensive growth. The lack of 
differences in plantlet growth responses after 15 days of recovery period also supported such a suggestion. These results were consistent with the results obtained by McCall and Brazaityte [12]. They have found that due to faster germination, Revido had a higher number of initiated leaves, a greater cotyledon length and area, and a greater shoot fresh weight than Matador at the start of the experimental period.

In our view, these results argue for rejecting the hypothesis that in addition to enhancing germination under optimal and stress conditions genes $a h$, $a w$ and $b l s$ might exercise similar effects on the subsequent seedling and plantlet growth. In some cases, as under direct sowing or slightly heated greenhouses, depending on the genotype and on the environmental conditions, the $a h-, a w-$ and $b l s-$ anthocyaninless lines might germinate earlier which might result in a more rapid plantlet development than that of the anthocyanin-containing one. Finally it could give a wrong idea that the anthocyaninless seedlings and plantlets developed more intensively under suboptimal conditions because of some favorable effect of these genes. However, it must be noted once again that seedling and plantlet performance was tested under stress conditions similar to those observed under unheated or slightly heated greenhouse, and not under a large scale of stress conditions. Consequently the probability that the anthocyaninless plants might differ in their reactions to other types of stress or to more intensive stress can not be completely rejected.

In conclusion, it might be assumed that the finding of a lack of correlation between the effect of genes $a h, a w$ and $b l s$ at germination and during the subsequent onthogenic stages under the stress conditions tested would not diminish the interest which these three genes could present for breeding programs. On the contrary, it confirms once again the importance of a fast germination for the initial plant stand. It shows also that although the effect of genes ah, aw and bls is likely to be limited to germination, this effect is not to be neglected as it significantly affects the initiation of the subsequent ontogenic stages.
Acknowledgment: This research is carried out with the support of the IAEA under Research Contract No. 7640/RB.

\section{References}

[1] Atanassova B., Shtereva L., Molle E., Effect of three anthocyaninless genes on germination in tomato (Lycopersicon esculentum Mill.). I. Seed germination under optimal conditions, Euphytica 95 (1997) 89-98.

[2] Atanassova B., Shtereva L., Molle E., Effect of three anthocyaninless genes on germination in tomato (Lycopersicon esculentum Mill.). II. Seed germination under stress conditions, Euphytica 97 (1997) 31-38.

[3] Duncan D.B., Multiple range and multiple F tests, Biometrics 11 (1955) 1-21.

[4] Foolad M.R., Response to Selection for Salt Tolerance during Germination in Tomato Seed Derived from PI 174263, J. Am. Soc. Hort. Sci. 121 (1996) 1011-1016.

[5] Foolad M.R., Jones R.A., Genetic analysis of salt tolerance during germination in Lycopersicon, Theor. Appl. Genet. 81 (1991) 321-326.

[6] Foolad M.R., Lin G.Y., Absence of a genetic relationship between salt tolerance during seed germination and vegetative growth in tomato, Plant Breeding 116 (1997) 363-367.

[7] Hashimoto T., Tajima M., Effects of ultraviolet irradiation on growth and pigmentation in seedlings, Plant Cell Physiol. 21 (1980) 1559-1571.

[8] Hoagland D.R., Arnon D., The water culture method for growing plants without soil, Calif. Agric. Exp. Stn Circ. 374 (1950) 1-32.

[9] Lakin G.F., Biometrics, "Vishaia Shcola", Moscow (1990) 350 (in Russian).

[10] Li J., Ou-Lee T., Raba R., Amundson R.G., Last R.L., Arabidopsis flavonoid mutants are hypersensitive to UV-B irradiation, Plant Cell 5 (1993) 171-179.

[11] Maxon Smith J.W., Ritchie D.B., A collection of near isogenic lines of tomato. Research tool of the future?, Plant Mol. Biol. Newslett. 3 (1982) 20-25.

[12] McCall D., Brazaityte A., Salinity effects on seedling growth and floral initiation in the tomato, Acta Agric. Scand. 47 (1997) 248-252.

[13] Muthiah S., David E.L., Harris W.M., Staging soybean seedling growth from germination to emergence, Crop Sci. 34 (1994) 289-292. 
[14] Orbovic V., Kieu K., A semi-automatic method for measurement of seedling length, Plant Growth Regul. 20 (1996) 303-305.

[15] Philouze J., Description of isogenic lines, except for one, or two, monogenically controlled morphological traits in tomato, Lycopersicon esculentum Mill., Euphytica 56 (1991) 121-131.

[16] Rick C.M., Chetelat R.T., Stocks Lists, TGC Rep. 43 (1993) 53-87.
[17] Scott S.J., Jones R.A., Cold tolerance in tomato. I. Seed germination and early seedling growth of Lycopersicon esculentum, Physiol. Plant. 65 (1985) 487-492.

[18] Scott S.J., Jones R.A., Cold tolerance in tomato. II. Early seedling growth of Lycopersicon ssp., Physiol. Plant. 66 (1986) 659-663.

[19] Yoder J.I., Belzile F., Tong Y., Goldsbrough A., Visual markers for tomato derived from the anthocyanin biosynthetic pathway, Euphytica 79 (1994) 163-167. 